\title{
The normal human newborns thymus
}

\author{
Jablonska-Mestanova $\mathrm{V}^{1}$, Sisovsky $\mathrm{V}^{2}$, Danisovic $\mathrm{L}^{3}$, Polak $\mathrm{S}^{4}$, Varga I ${ }^{4}$ \\ Institute of Histology and Embryology, Faculty of Medicine, Comenius University, Bratislava, Slovakia. \\ ivan.varga@fmed.uniba.sk
}

\begin{abstract}
The thymic microenvironment constitutes a unique cell environment composed of thymic epithelial cells, myoid cells, and bone marrow-derived accessory cells for the differentiation, maturation and selection of $\mathrm{T}$ lymphocytes. The histological feature of thymus is markedly dependent on the age of individual and on various negative stimuli. Our study group consisted of fourteen newborns whose thymuses were removed during surgery performed for various congenital heart defects. We used a palette of seven monoclonal antibodies for exact localization of different cells creating the thymic microenvironment (cytokeratin AE1/AE3, desmin, actin, S100 protein, CD68, CD20, and CD45RO) as well as three monoclonal antibodies against proteins regulating the process of apoptosis (bcl2 oncoprotein, p53 protein, and survivin). We described and microphotographically illustrated the localization of thymic cytokeratin AE1/AE3-positive epithelial cells (subcapsular part of the cortex and medulla, especially Hassall's corpuscles), dendritic cells (medulla, often inside the Hassall's corpuscles), thymic myoid cells (medulla, often in close contact with Hassall's corpuscles), macrophages (mostly cortex, but also medulla and inside the Hassall's corpuscles), B lymphocytes (thymic medulla) and CD45RO-positive T lymphocytes (mostly thymic cortex). We found p53-positive thymic epithelial cell nuclei in subcapsular part of cortex and in outer epithelial cell layer of Hassall's corpuscles (very similar to the basal layer of epidermis). $\mathrm{Bcl} 2$ positive lymphocytes were mostly localized in thymic medulla, especially nearby Hassall's corpuscles. The thymuses were mostly survivin-negative with exception of round cells in border between cortex and connective tissue septa (probably migrating progenitor cells) (Tab. 1, Fig. 14, Ref. 66). Full Text in PDF www.elis.sk. Key words: thymus, microenvironment, thymic epithelial cells, myoid cells, macrophages, dendritic cells, apoptosis, immunohistochemistry.
\end{abstract}

Since the first description by Claudius Galenos of Pergamon (130-200 AD), the thymus has remained an "organ of mystery" throughout the 2,000 years of history of medicine $(1,2)$. The thymus is an important organ for the development of T lymphocyte dependent immune system. Such an important thymus, however, is known to start to involute around at puberty and its function is believed to become marginal in the late adulthood and in the elderly (3). Most people believe that atrophic fatty thymuses of human adults are not working anymore, while, Douek et al (4) reported that the thymuses of human adults were still capable of producing $\mathrm{T}$ lymphocytes. Therefore we think that the classical Czech and Slovak term for thymus as "child gland" is not suitable.

The general microscopic description of human thymus is very complicated, because the thymus is a very dynamic organ that

${ }^{1}$ Institute of Histology and Embryology, Jessenius Faculty of Medicine, Comenius University, Martin, Slovakia, ${ }^{2}$ Institute of Pathology, Faculty of Medicine, Comenius University Bratislava, Slovakia, ${ }^{3}$ Institute of Medical Biology, Genetics and Clinical Genetics, Faculty of Medicine, Comenius University, Bratislava, Slovakia, and ${ }^{4}$ Institute of Histology and Embryology, Faculty of Medicine, Comenius University, Bratislava, Slovakia

Address for correspondence: I. Varga, RND, PhD, Institute of Histology and Embryology, Faculty of Medicine, Comenius University, Sasinkova 4, SK-811 08 Bratislava, Slovakia.

Phone: +421.2 .59357547$

Acknowledgement: This study was supported by the VEGA grant agency of the Slovak Ministry of Education No. 1/0902/11 (Thymus in human ontogenesis). rapidly changes under exogenous negative stimuli (e.g. hormones, pesticides, certain diseases, poor nutrition, stress, and radiotherapy) and it involutes with age (5-7). The thymus is most active during fetal and early postnatal period, generating a diverse repertoire of $\mathrm{T}$ lymphocytes (8). One of the most striking features of thymus physiology is its age-related involution with dramatic decrease in cellular content and volume of the organ. But the persistent parts of thymus after age-related involution localized inside the adipose tissue are not only simple thymic fragments. They are composed of cortical and medullar portions (3), and are actually capable of providing a certain number of $\mathrm{T}$ lymphocytes in young and old adults (9).

Thymus plays an important role in providing a suitable microenvironment for the proliferation, differentiation, TCR gene rearrangement and repertoire selection of T cells $(10,11)$. The differentiation of T cells is a carefully orchestrated process supported by the thymic microenvironment, composed of thymic epithelial cells, fibroblasts, thymic myoid cells, and bone marrow-derived accessory cells such as B lymphocytes, macrophages and dendritic cells $(12,13)$. The mechanisms by which mutual interactions between T lymphocyte precursors and thymic stromal cells control $\mathrm{T}$ lymphocyte differentiation have been the subject of extensive studies, leading to an increasing understanding of the mechanisms of thymic education process $(14,15)$.

Newborn, whether premature or of normal gestational age, is a unique host from an immunological perspective. A certain reduction of the functional capabilities of many components of the 
Tab. 1. Characteristics of the used monoclonal antibodies.

\begin{tabular}{|c|c|c|c|}
\hline Expression of & Description & Detection of & Catalog Code Number \\
\hline Cytokeratin AE1/AE3 & $\begin{array}{l}\text { Family of water-soluble proteins that form the cytoskeleton of epi- } \\
\text { thelial cells }\end{array}$ & $\begin{array}{l}\text { Thymic epithelial } \\
\text { cells }\end{array}$ & $\begin{array}{l}\text { Dako, Denmark, } \\
\text { No. M3515 }\end{array}$ \\
\hline $\mathrm{S} 100$ & $\begin{array}{l}\mathrm{Ca} 2+\text {-dependent regulation of a variety of intracellular activities, } \\
\text { e.g. protein phosphorylation, cell proliferation, and differentiation }\end{array}$ & Dendritic cells & $\begin{array}{l}\text { Dako, Denmark, } \\
\text { No. Z0311 }\end{array}$ \\
\hline CD68 & $\begin{array}{l}\text { Glycoprotein highly expressed by human monocytes and tissue } \\
\text { macrophages }\end{array}$ & Macrophages & $\begin{array}{l}\text { Dako, Denmark, } \\
\text { No. M0876 }\end{array}$ \\
\hline Desmin & $\begin{array}{l}\text { Forms a cytoskeletal network across the muscle fibre, specific for } \\
\text { smooth and striated muscle cells }\end{array}$ & Thymic myoid cells & $\begin{array}{l}\text { Dako, Denmark, } \\
\text { No. M0724 }\end{array}$ \\
\hline Actin & $\begin{array}{l}\text { Belongs to the microfilament system of cytoskeleton proteins of } \\
\text { smooth muscle cells, myofibroblasts and myoepithelial cells }\end{array}$ & Thymic myoid cells & $\begin{array}{l}\text { Dako, Denmark, } \\
\text { No. M085129 }\end{array}$ \\
\hline Survivin & $\begin{array}{l}\text { Member of the inhibitor of apoptosis protein family, suppresses } \\
\text { apoptosis and regulates cell division }\end{array}$ & Apoptosis & $\begin{array}{l}\text { Dako, Denmark, } \\
\text { No. M3624 }\end{array}$ \\
\hline $\mathrm{Bc} 12$ oncoprotein & Plays a central role in apoptosis, blocker of apoptotic cell death & Apoptosis & $\begin{array}{l}\text { Dako, Denmark, } \\
\text { No. M0887 }\end{array}$ \\
\hline CD20 & $\begin{array}{l}\text { Located on the surface of B cells. CD20 appears early during B-cell } \\
\text { maturation and is lost shortly before the terminal plasma cell stage. }\end{array}$ & B- lymphocytes & $\begin{array}{l}\text { Dako, Denmark, } \\
\text { No. M0755 }\end{array}$ \\
\hline CD45RO & $\begin{array}{l}\text { Antibody labels most thymocytes, a subpopulation of resting T cells } \\
\text { within both CD } 4 \text { and CD8 subsets, and mature, activated T cells }\end{array}$ & T- lymphocytes & $\begin{array}{l}\text { Dako, Denmark, } \\
\text { No. M0742 }\end{array}$ \\
\hline
\end{tabular}

immune system observed in neonates compared with adults has been explained on the basis of both the immaturity and the naïveté of the neonatal immune system. After delivery thymus undergoes a transient involution with changes in thymic microenvironment (16). In our preliminary immunohistochemical study we described the localization of different cells creating the thymic microenvironment as well as the markers of apoptosis in thymuses from normal human newborns.

\section{Patients and methods}

The study group consisted of 14 newborns (from delivery to 1 month of age) whose thymuses were removed (partial thymectomy) during surgery performed for various congenital heart defects (e.g. ventricular septal defect, atrioventricular septal defect, tetralogy of Fallot).

The specimens were fixed in formalin for $24 \mathrm{~h}$, embedded in paraffin, and $5 \mu \mathrm{m}$ thick sections were used for immunohistochemistry. Sections were stained for the expression of cytokeratin AE1/ AE3, desmin, actin, S100 protein, CD68, CD20 and CD45RO, for complex visualization of all cells which create the thymic microenvironment. We used also antibodies against pro-apoptotic and anti-apoptotic proteins (p53 protein, bcl2 oncoprotein and survivin) for visualization of the process of apoptosis in thymus (Tab. 1). The final reaction product was visualized with diaminobenzidine as chromogen in brown. Cell nuclei were stained with Mayer's hematoxylin.

Histological examination was performed by LEICA DM2500 microscope and images were captured with LEICA DFC290HD digital camera.

\section{Results}

Cytokeratines are a family of water-soluble proteins which form one type of intermediary filaments. They participate in the formation of epithelial cell cytoskeleton. In our slides, cytokeratin AE1/ AE3 positivity of some thymic epithelial cells was found. They were localized mostly in subcapsular region of cortex creating very tiny stripe dividing cortex from tissue capsule and septa of thymus (Fig. 1). Moreover, cytokeratine AE1/AE3 positive epithelial cells were detected to be part of thymic Hassall's corpuscles (Fig. 2).

We observed sections stained by two different markers for myoid cells. Myoid cells of thymus have spindle-like shape with centrally localized nucleus which was negative for actine and des$\min$ (Figs 3, 4). Myoid cells were localized in medulla exclusively and often in tight proximity of Hassall's corpuscles. In few cases these cells were included in outer layer of Hassall's corpuscles.

S100 protein positive components of thymus, interdigitating dendritic cells including, showed marked positivity in thymic medulla and cortico-medullary junction (Fig. 5). Cells were localized nearby Hassall's corpuscles and also in some cases inside the Hassall's corpuscles, too (Fig. 6). In the cortex, presence of positive cells was very rare.

CD68-positive cells, macrophages, were detected in every part of thymus, in cortex, medulla and even in connective tissue septa. The highest prevalence was observed in cortical part (Fig. 7) and cortico-medullary junction where these cells were deployed equally. Hassall's corpuscles included CD68-positive cells in their structure as well (Fig. 8).

CD20 positive cells - B lymphocytes - were localized exclusively in thymic medulla (Fig. 9) and CD45RO positive cells - T 


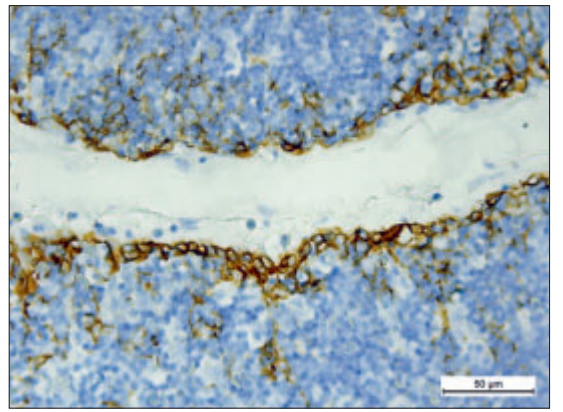

Fig. 1. Thymic cortex of three week old male with congenital malformation of tricuspid valve; cytokeratin AE1/AE3-positivity of subcapsular epithelial cells (Magn. 400x).

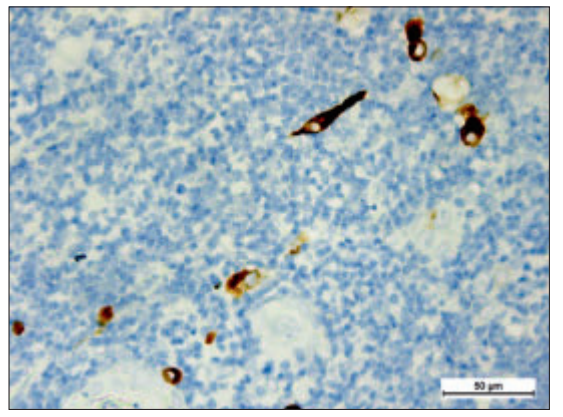

Fig. 4. Thymic medulla of four week old male with congenital stenosis of aortal valve; spindle-shape myoid cells (anti-desmin) (Magn. 400x).

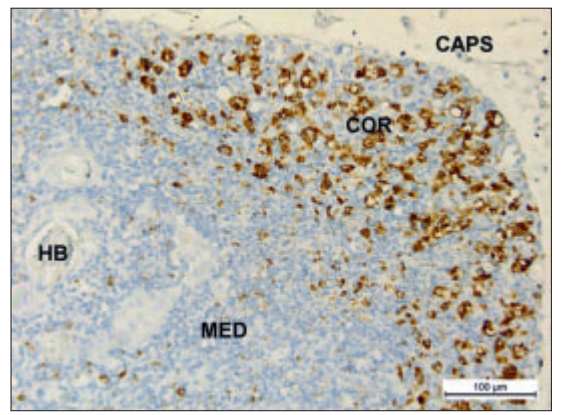

Fig. 7. Thymus of four week old male with pulmonary valveatresia; macrophagesin thymiccortex w (anti-CD68, CAPS-capsule, COR-cortex, MED phages inside the Hassall's corpuscles (anti- medulla, HB - Hassall's body) (Magn. 200x). CD68) (Magn. 400x).

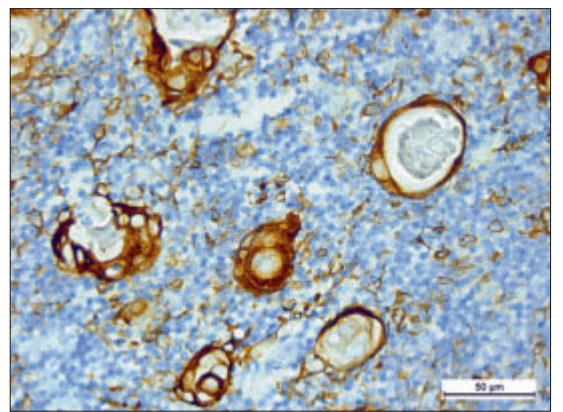
Hassall's corpuscle (Magn. 400x).
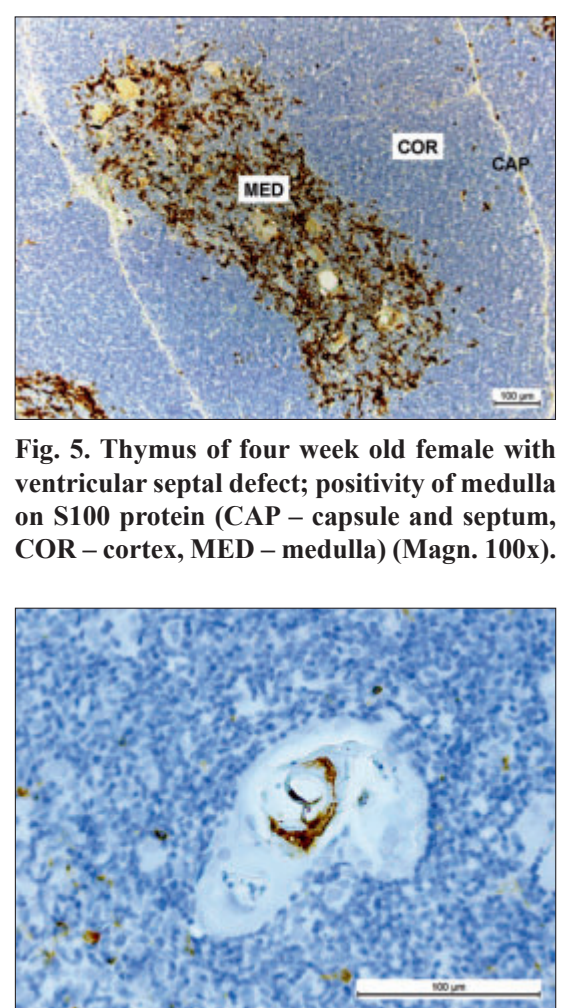

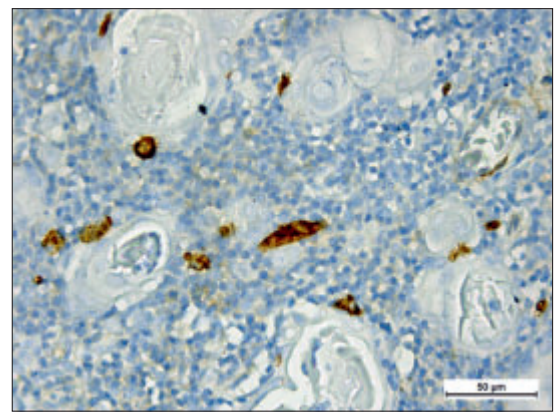

Fig. 2. Thymic medulla of four week old male Fig. 3. Thymic medulla of four week old female with transposition of great arteries; cytoker- with hypoplastic left heart syndrome; spindle-

(anti-actin) (Magn. 400x).

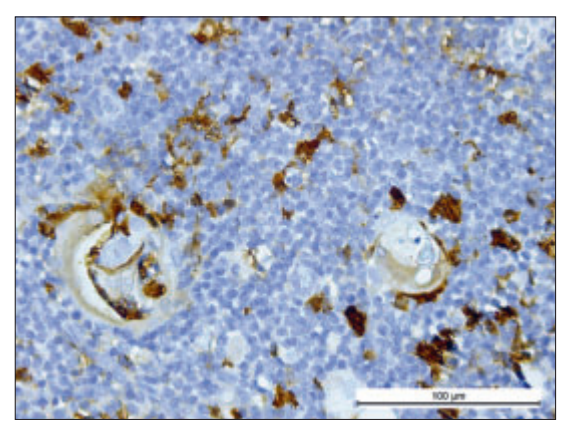

Fig. 5. Thymus of four week old female with Fig. 6. Thymic medulla of one week old male entricular septal defect; positivity of medulla with double-outlet right ventricle; S100 proon S100 protein (CAP - capsule and septum, tein-positive structures inside the Hassall's corCOR - cortex, MED - medulla) (Magn. 100x). puscles (Magn. 400x).

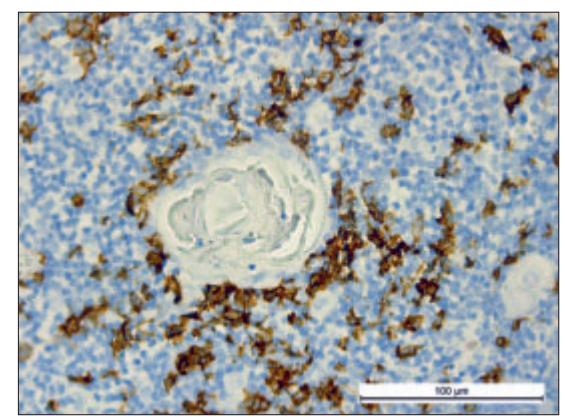

Fig. 9. Thymic medulla of four week old male with double-outlet right ventricle; CD20-positive B lymphocytes concentrated around Hassall's corpuscles (Magn. 400x). lymphocytes - were localized throughout thymic parenchyma, but mostly in thymic cortex (Fig. 10). Numerous CD20 positive cells were especially concentrated around Hassall's cospuscles.

p53 protein as an apoptosis inductor was demonstrated in nuclei of some thymic epithelial cells. These positive cells were localized exclusively in subcapsular region of the cortex (Fig. 11) and forming outer layer of flattened cells of Hassall's corpuscles (Fig. 12).

Oncoprotein bcl2 prevents apoptosis and interpretation of immunohistochemical proof showed that the majority of positive cells occur in medulla, less in cortex. In general, lymphocytes nuclei showed positivity, the most of them localized in medulla, in cortex bcl2-positive cells occurred occasionally. The highest positivity was observed in lymphocytes nuclei close to the Hassall's corpuscles (Fig. 13). This fact may represent a connection between Hassall's corpuscles and regulation of lymphocytes apoptosis.

Survivin, anti-apoptosis protein, showed negativity in majority of examined thymuses. But occurrence of survivin-positive cells (cytoplasmic positivity) in subcapsular region of cortex, on border of cortex and connective tissue capsule, was a very interest- 

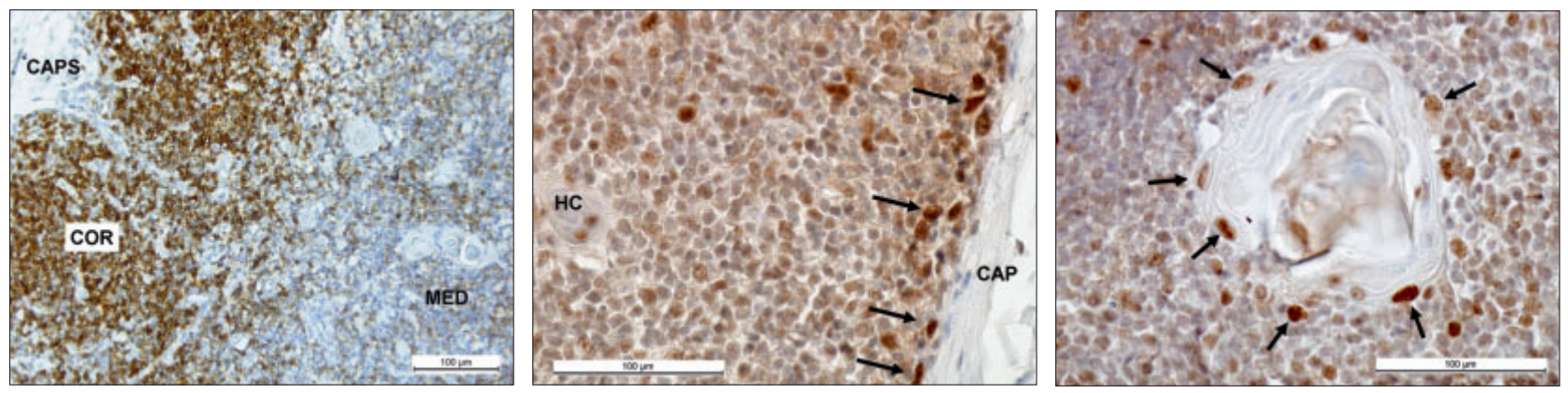

Fig. 10. Thymus of three week old male with trans- Fig.11. Thymic cortex of four week old female with Fig. 12. Thymic medulla of four week old male position of great arteries; CD45RO-positive T ventricular septal defect; p53-positivenuclei of ep- with double-outlet right ventricle; p53-positive lymphocytes localized mostly in cortex (COR) ithelial cells (arrows) in subcapsular region (CAP nuclei of epithelial cells (arrows) forming outer (CAPS-capsule, MED-medulla) (Magn. 200x). - capsule, HC-Hassall's corpuscle)(Magn. 400x). layer of Hassall's corpuscle (Magn. 400x).

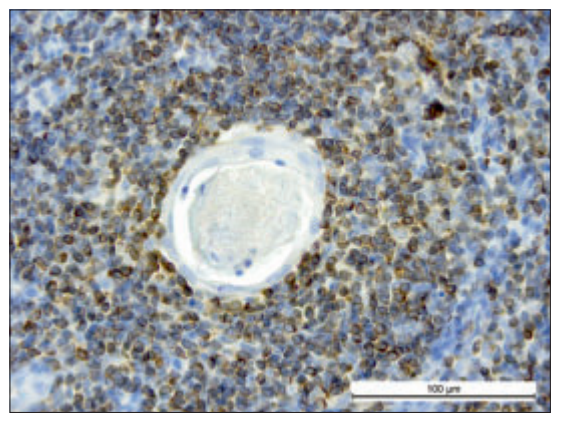

Fig. 13. Thymic medulla of four week old female with ventricular septal defect; Bcl2-positive lymphocytes concentrated around Hassall's corpuscles (Magn. 400x).

ing finding (Fig. 14). We assume that these cells can be migrating progenitor cells originating from bone marrow.

\section{Discussion}

\section{Thymic myoid cells and desmin and actin}

Cells with myofibrils and all of the characteristics of striated muscle fibers are present in the thymuses of various species of fish, amphibians, reptiles, birds and mammals. They are especially abundant in the thymuses of young individuals (17). The thymic myoid cells were first noted in 1888 by Mayer, who saw them in the frog thymus; they were described as a long, spindle-shaped cells showing distinct striations and closely resembling rudimentary skeletal muscle fibers (18). In human, myoid cells are rare and located mainly in the medulla (19) and are most abundant in fetal development (17). These conclusions are similar to our results, we found spindle-shaped myoid cells in the medulla, often in a close relationship with Hassall's corpuscles, in newborns thymuses.

Thymic myoid cells express muscle proteins including desmin, actin, five subunits of acetylcholine receptor, myosin, troponin and myogenic transcription factor $(20,21)$. From this palette of proteins in our study we used monoclonal antibodies against desmin and actin. Desmin belongs to the class III of intermediate filaments, constituting part of the cytoskeleton, and is the char-

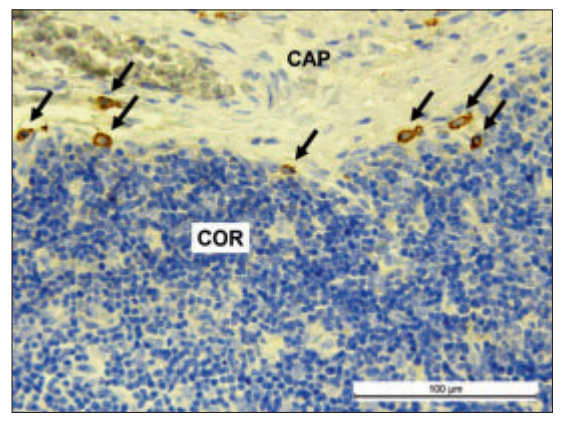

Fig. 14. Thymic cortex of three week old male with transposition of great arteries; survivin-positive cells (arrows) in borderline between connective tissue capsule (CAP) and cortex (COR) (Magn. 400x).

acteristic intermediate filament of all three types of muscle cells (skeletal, cardiac and smooth muscle) (22). Cytoplasmic actins belong to the microfilament system of cytoskeleton proteins of smooth muscle cells, myofibroblasts and myoepithelial cells (23).

The embryonic origin and exact role in thymic physiology of myoid cells are unknown. Hammar (24) considered that established thymic epithelial cells may give rise to myoid elements. Raviola and Raviola (25) conclude on the basis of ultrastructural studies that muscle filaments may develop in cells that closely resemble thymic epithelial cells. Van de Velde and Friedman (17) described extra-thymic origin of myoid cells from perithymic mesenchyme that enter the thymic primordial secondary. Today, the hypothesis of Nakamura and Ayer-Le Liére (26) is the most accepted, where they suggest a neuroectodermal origin of myoid cells. That is, they are derivatives of the neural crest.

The biological role of myoid cells is not yet clear. Raviola and Raviola (25) suggest that myoid cells play a mechanical role in facilitating lymphocyte passage through the thymus by their spasmodic contraction. On the other hand, Tamiolakis et al (27) demonstrated that myoid cells are involved in the formation of a suitable microenvironment for proliferation of erythropoietic cells in fetal thymuses between 16th and 20th week of development. Mesnard-Rouller et al (20) suggest that since myoid cells express high level of most muscle genes and are consistently found in the 
thymic medulla, they may contribute to the mechanisms involved in the induction and maintenance of immune tolerance. Myoid cells have, similarly to thymic epithelial cells, surface receptors for acetylcholine (28). Thereby, it is presumable that both cell types can play an initial role in the auto-sensitization during the autoimmune disease myasthenia gravis. In recent years, the involvement of myoid cells in pathogenesis of myasthenia gravis has been suggested $(29,30)$. In opposite, according to Matsumoto et al (31) expansion of myoid cells in thymus may not directly cause myasthenia gravis.

Wakkach et al (32) demonstrate the excessive production of TNF- $\alpha$ and IL- 8 in tissue cultures of myoid cells. These factors presumably protect lymphocytes from apoptosis and myoid cells play an important role in the differentiation of T lymphocytes. The protective effect of myoid cells against apoptosis of lymphocytes in in vitro conditions is described also by Le Pensé-Ruskoné and Berrih-Aknin (21) and Panse and Berrih-Aknin (33), and in vivo by Varga et al (34).

\section{Thymic epithelial cells and cytokeratins AE1/AE3}

Many authors were concerned with the study of heterogeneity of the thymic epithelial cells, but it wasn't until Wijngaert et al (35) that they were classified in humans. The criterion was based on the ultrastructural morphology. The heterogeneity of the epithelial cells of the thymus manifests not only morphologically, but also in phenotype expression of different markers. Certain subtypes of thymic epithelial cells - the medullary epithelium and the subcapsullar epithelium - show strong immunohistochemical reactivity with antisera against oxytocin, Arg-vasopressin and neurophysin. The epithelial nature of the neuropeptide containing cells is shown by their morphology and their reactivity with monoclonal anti-cytokeratin AE1/AE3. Hassall's corpuscles are positive as well (36). The different positivity for cytokeratin AE1/ AE3 among epithelial cells was also seen in our study.

The thymic epithelial cells support the development of the organ specific tumors of the thymus, known thymomas. Thymoma is a relatively rare neoplastic condition with unpredictable behavior and few molecular factors were shown to be useful to predict the outcome of the patient (37). Positivity of epithelial cells on cytokeratin $\mathrm{AE} 1 / \mathrm{AE} 3$ is used for differential diagnosis of primary thymic epithelial tumors of the pleura mimicking malignant mesothelioma (38).

\section{Bone marrow-derived cells of thymus}

In the thymus the bone-marrow derived cells include T-lineage cells as the dominant cell type, together with a low level of B lymphocytes, macrophages and dendritic cells. Monocytes entering the thymus differentiate into macrophages, which are situated mainly in the cortex and on the cortico-medullary junction, or into dendritic cells, which are typical for the medulla and cortico-medullary junction (39).

CD68 protein belongs to a family of lysosomal glycoprotein/ plasma membrane shuttling proteins that play a role in endocytosis and/or lysosomal trafficking. CD68 is expressed strongly in cytoplasmic granules, and weakly on the surface of macrophages, monocytes, neutrophils, basophils and NK-cells. Unlike many other CD leukocyte antigens, the CD68 molecule is antigenically very heterogeneous, and different antibodies to CD68 show different cellular reactivity (40). The function of macrophages during $\mathrm{T}$ lymphocytes development is not completely understood. It seems clear that macrophages participate in the removal of apoptotic lymphocytes, because almost all lymphocytes (95-97\%) are removed by apoptosis during their development in the thymus. Therefore the cortical macrophages are professional "scavengers" of apoptotic cells (41). Less accepted is, however, macrophages implication in the regulation of the survival, proliferation, MHC restriction, or negative selection of developing lymphocytes (42).

Dendritic cells are professional antigen presenting cells that form a dynamic network throughout most tissues and organs and that are crucial for the immune surveillance of the body. Human thymus contains two distinct populations of dendritic cells with typical dendritic morphology (43). The identification of the thymic dendritic cells is not possible using conventional light microscopy. They can be easily identified using monoclonal antibodies. For immunohistochemical demonstration of thymic dendritic cells we used antibodies against S100 protein, which was previously used by Savchenko et al (44), Lee and Wright (45) and Aita et al (46). We found S100 positive cells not only in medulla, but also inside the Hassall's corpuscles. That confirms the existence of dendritic cells inside the Hassall's corpuscles as was previously described by Raica et al (47) and Raica et al (48).

\section{Thymus and markers of apoptosis (p53, bcl2 and survivin)}

Majority of publications in databases Web of Science, Medline/ PubMed or Scopus about expression of apoptosis markers deals only with thymic neoplasm. Many researchers focused on the expression of $\mathrm{p} 53, \mathrm{Bcl} 2$ and survivin as a very important diagnostic tool in thymic pathology, especially in thymic epithelial neoplasm, where the classification remains controversial (49).

Several oncogenes and tumor-suppressor genes are known to regulate apoptosis. The $p 53$ protein is a nuclear phosphoprotein and normally mediates apoptosis (50). Wild-type p53 protein is present in a wide variety of normal cells, but the protein has a very short half-life and thus is present in only minute amounts (51), generally below the detection level of immunocytochemical methods (52). Wild-type $\mathrm{p} 53$ protein functions as a transcription factor, i.e. as a modulator which can turn crucial genes either on or off. It also inhibits DNA replication and is a check-point control molecule for progression of the cell cycle. Furthermore, p53 protein is involved in the regulation of apoptosis $(53,54)$. We observed strong p53 nuclear staining in outer cell layer of epithelial cells of Hassall's corpuscles and subcapsular epithelial cells. Positivity of p53 in epithelial cells was also described by Di Como et al (55) and Dotto et al (56). The expression of p53 between outer layer of epithelial cells of Hassall's corpuscles and basal layer of epidermis of skin is very similar. In the epidermis the positivity for $\mathrm{p} 53$ protein occurs only in the basal layer (57).

Bcl 2 oncoprotein is a blocker of apoptotic cell death. Gene transfer experiments have shown that elevated levels of this protein can protect a wide variety of cells from diverse cell death stimuli ranging from growth factor withdrawal and cyto- 
toxic lymphokines to virus infection and DNA-damaging, anticancer drugs and radiation $(58,59)$. Bcl2 protein was strongly expressed in medullary lymphocytes of normal thymuses also in study of Park et al (60). A strong expression of Bcl2 protein is typical also in cases of thymic carcinomas (61).

Recently, antiapoptic protein survivin is in the centre of intensive medical research. It can be detected in tissues especially during embryonic and fetal development in most types of malignant tumors, but it is expressed relatively poorly in normal adult tissues $(62,63)$. Increased expression of survivin is in many malignant diseases associated with aggressive tumor growth, decreased survival of patients and impaired response to chemotherapy treatment $(64,65)$. Survivin is very important in cell death, as well as in cell proliferation. We assume that survivin-positive cells detected at the interface of connective tissue septa and cortex are actively dividing progenitor cells of $\mathrm{T}$ lymphocytes. This hypothesis is also evidenced by results of Xing et al (66), who suggests that survivin in the thymus does not play a role in apoptosis, but is important for the maturation and proliferation of T-lymphocytes.

\section{References}

1. Nishino M, Ashiku SK, Kocher ON, Thurer RL, Boiselle PM, Hatabu H. The thymus: a comprehensive review. Radiographics 2006; 26: 335-348.

2. Kachlik D, Baca V, Bozdechova I, Cech P, Musil V. Anatomical terminology and nomenclature: past, present and highlights. Surg Radiol Anat 2008; 30: 459-466.

3. Shiraishi J, Utsuyama M, Seki S, Akamatsu H, Sunamori M, Kasai M, Hirokawa K. Essential microenvironment for thymopoiesis is preserved in human adult and aged thymus. Clin Dev Immunol 2003; 10 (1): 53-59.

4. Douek DC, McFarland RD, Keiser PH, Sullivan JL, Jamieson BD, Zack JA, Picker LJ, Koup RA. Changes in thymic function with age and during the treatment of HIV infection. Nature 1998; 396: 690-695.

5. Bodey B, Bodey BJr, Siegel S, Keiser HE. Involution of the mammalian thymus, one of the leading regulators of aging. In Vivo 1997; 11: 421-440.

6. Dorko F, Kluchová D, Boleková A, Špakovská T, Borošová T, Lovasová $K$. Influence of surgical and chemical orchidectomy on weight and distribution of AChE-nerve fibers in thymuses of adult rats. Eur $\mathrm{J}$ Histochem 2011; 55: e22.

7. Dorko F, Danko J, Flešárová S, Boroš E, Sobeková A. Effect of pesticide bendiocarbamate on distribution of acetlycholine- and butyrylcholinepositive nerves in rabbit's thymus. Eur J Histochem 2011; 55 (4): e37.

8. Rezzani R, Bonomini F, Rodella LF. Histochemical and molecular overview of the thymus as site fot T-cells development. Prog Histochem Cytochem 2008; 43: 73-120.

9. Bertho JM, Demarquay C, Moulian N, van der Meeren A, Berrih-Aknin S, Gourmelon P. Phenotypic and immunohistochemical analyses of the human adult thymus: evidence for an active thymus during adult life. Cell Immunol 1997; 179: 30-40.

10. Guyden JC, Pezzano M. Thymic nurse cells: a microenviroment for thymocyte development and selection. Int Rev Cytol 2003; 223: 1-37.

11. Laurent J, Bosco N, Marche PN, Ceredig R. New insight into the proliferation and differentiation of early mouse thymocytes. Int Immunol 2004; 16 (8): 1069-1080.
12. Boyd RL, Tucek CT, Godfrey DI, Izon DJ, Wilson TJ, Davidson NJ, Bean AGD, Ladyman HM, Ritter MA, Hugo P. The thymic microenvironment. Immunol Today 1993; 14 (9): 445-459.

13. Varga I, Mikusova R, Pospisilova V, Galfiova P, Adamkov M, Polak S, Galbavy S. Morphologic heterogeneity of human thymic nonlymphocytic cells. Neuroendocrinol Lett 2009; 30 (3): 275-283.

14. Anderson G, Harman BC, Hare KJ, Jenkinson EJ. Microenvironmental regulation of $\mathrm{T}$ cell development in the thymus. Immunology 2000; 12: 457-464.

15. Anderson G, Jenkinson EJ. Lymphostromal interactions in thymic development and function. Nat Rev Immunol 2001; 1: 31-40.

16. Varas A, Jiménez E, Sacedón R, Rodríguez-Mahou M, Maroto E, Zapata AG, Vicente A. Analysis of the human neonatal thymus: evidence for a transient thymic involution. J Immunol 2000; 164 (12): 6260-6267.

17. Van de Velde RL, Friedman NB. Thymic myoid cells and myasthenia gravis. Am J Pathol 1970; 59 (2): 347-368.

18. Mayer S. Zur lehre von der Schilddrüse und thymus bei Amphibien. Anat Anz 1888; 3: 97-103.

19. Schluep M, Willcox N, Vincent A, Dhoot GK, Newsom-Davis J. Acetylcholine receptors in human thymic myoid cells in situ: an immunohistological study. Ann Neurol 1987; 22 (2): 212-222.

20. Mesnard-Rouiller L, Bismuth J, Wakkach A, Poëa-Guyon S, Berrih-Aknin S. Thymic myoid cells express high levels of muscle genes. J Neuroimmunol 2004; 148 (1-2): 97-105.

21. Le Panse-Ruskoné R, Berrih-Aknin S. Human myoid cells protect thymocytes from apoptosis. Ann N Y Acad Sci 2003; 998: 266-269.

22. Goebel HH, Warlo IAP. Progress in desmin-related myopathies (review). J Child Neurol 2000; 15: 565-572.

23. Roholl PJM, Elbers HRJ, Prinsen I, Claessens JAJ, van Unnik JAM. Distribution of actin isoforms in sarcomas: an immunohistochemical study. Hum Pathol 1990; 21: 1269-1274.

24. Hammar JA. Zur histogenese und involution der thymus drüse. Anat Anz 1905; 37: 23-30.

25. Raviola E, Raviola G. Straited muscle cells in the thymus of reptiles and birds: an electron microscopic study. Am J Anat 1967; 121 (3): 623-645.

26. Nakamura H, Ayer-Le Liére C. Neural crest and thymic myoid cells. Curr Top Dev Biol. 1986; 20: 111-115.

27. Tamiolakis D, Venizelos J, Kotini A, Karamanidis D, Boglou P, Papadopoulos N. A stromal myoid cell line provokes thymic erythropoiesis between 16th to 20th weeks of intrauterine life. East Afr Med J 2004; 81 (2): 78-81.

28. Wakkach A, Guyon T, Bruand C. Expression of acetylcholine receptors gene in human thymic epithelial cells: implications for myasthenia gravis. J Immunol 1996; 157: 3752-3760.

29. Roxanis I, Micklem K, McConville J, Newsom-Davis J, Willcox N. Thymic myoid cells and germinal center formation in myasthenia gravis; possible roles in pathogenesis. J Neuroimmunol 2002; 125 (1-2): 185-197.

30. Bornemann A, Kirchner T. Thymic myoid cell turnover in myasthenia gravis patients and in normal controls. Virchows Arch 1998; 432 (4): 357-361.

31. Matsumoto MY, Matsuo H, Oka T, Fukudome T, Hayashi K, Shiraishi H, Motomura M, Shibuya N, Ayabe H. Thymic myoid cells as a myasthenogenic antigen and antigen-presenting cells. J Neuroimmunol 2004; 150 (1-2): 80-87. 
32. Wakkach A, Poea S, Chastre E, Gespach C, Lecerf F, de la Porte S, Tzartos S, Coulombe A, Berrih-Aknin S. Establishment of a human thymic myoid cell line. Phenotypic and functional characteristics. Am J Pathol 1999; 155 (4): 1229-1240.

33. Panse Le R, Berrih-Aknin S. Thymic myoid cells protect thymocytes from apoptosis and modulate their differentiation: impli implication of the ERK and Akt signaling pathways. Cell Death Differ 2005; 12: 463-472.

34. Varga I, Sisovsky V, Jablonska - Mestanova V, Polak S, Adamkov M. Thymic myoid cells could protect lymphocytes in thymic medulla from apoptosis in vivo: a preliminary immunohistochemical study. Virchows Archiv 2011; 459 (Suppl. 1): S54-S55.

35. Wijngaert FP van de, Kendall MD, Schuurman HJ, Rademakers LHMP, Kater L. Heterogeneity of human thymus epithelial cells: an ultrastructural study. Cell Tissue Res 1984; 237: 227-237.

36. Moll UM, Lane BL, Robert F, Geenen V, Legros JJ. The neuroendocrine thymus. Abundant occurrence of oxytocin-, vasopressin-, and neurophysin-like peptides in epithelial cells. Histochemistry 1988; 89 (4): 385-390.

37. Raica M, Kondylis A, Mogoanta L, Encica S, Cîmpean AM. Diagnostic and clinical significance of D2-40 expression in the normal human thymus and thymoma. Rom J Morphol Embryol 2010; 51 (2): 229-34.

38. Attanoos RL, Galateau-Salle F, Gibbs AR, Muller S, Ghandour F, Dojcinov SD. Primary thymic epithelial tumours of the pleura mimicking malignant mesothelioma. Histopathology 2002; 41 (1): 42-49.

39. Wu L, Shortman K. Heterogeneity of thymic dendritic cells. Sem Immunol 2005; 17: 304-312.

40. Falini B, Flenghi L, Pileri S, Gambacorta M, Bigerna B, Durkop H, Eitelbach F, Thiele J, Pacini R, Cavaliere A et al. PG-M1: A new monoclonal antibody directed against a fixativeresistant epitope on the macrophage-restricted form of the CD68 molecule. Am J Pathol 1993; 142: 1359-1372.

41. Wakimoto T, Tomisaka R, Nishikawa Y, Sato H, Yoshino T, Takahashi K. Identification and characterization of human thymic cortical dendritic macrophages that may act as professional scavengers of apoptotic thymocytes. Immunobiology 2008; 213 (9-10): 837-847.

42. Varas A, Sacedón R, Hernandez-López C, Jiménez E, Garcia-Ceca J, Arias-Diaz J, Zapata AG, Vicente A. Age-dependent changes in thymic macrophages and dendritic cells. Microsc Res Techn 2003; 62: 501-507.

43. Vandenabeele $S$, Hochrein H, Mavaddat N, Winkel K, Shortman K. Human thymus contains 2 distinct dendritic cell populations. Blood 2001; 97 (6): 1733-1741.

44. Savchenko AS, Hasegawa G, Naito M. Development and maturation of thymic dendritic cells during human ontogeny. Cell Tissue Res 2006; 325 (3): 455-460.

45. Lee D, Wright DH. Immunohistochemical study of 22 cases of thymoma. J Clin Pathol 1988; 41: 1297-1304.

46. Aita M, Franzé A, Gabrielli F. S-100 immunoreactive interdigitating cells in normal and in Down's syndrome human thymuses. Cell Biol Int Rep 1991; 15 (8): 645-659.

47. Raica M, Encica S, Motoc A, Cimpean AM, Scridon T, Barsan M. Structural heterogeneity and immunohistochemical profile of Hassall corpuscles in normal human thymus. Ann Anat 2006; 188 (4): 345-352.

48. Raica M, Cimpean AM, Encica S, Cornea R. Involution of the thymus: a possible diagnostic pitfall. Rom J Morphol Embryol 2007; 48 (2): 101-106.

49. HiroshimaK,IyodaA,ToyozakiT,SupriatnaY,Shibuya K,Shimamura F, Haga Y, Yoshida S, Fujisawa T, Ohwada H. Proliferative activity and apoptosis in thymic epithelial neoplasms. Mod Pathol 2002; 15 (12): 1326-1332.
50. Levine AJ. p53, the cellular gatekeeper for growth and division. Cell 1997; 88: 323-331.

51. Vojtěsek B, Bártek J, Midgley CA, Lane DP. An immunochemical analysis of the human nuclear phosphoprotein p53. New monoclonal antibodies and epitope mapping using recombinant p53. J Immunol Methods 1992; 151: 237-244.

52. Cooper K, Haffajee Z. bcl-2 and p53 protein expression in follicular lymphoma. J Pathol 1997; 182: 307-310.

53. Nieder C, Petersen S, Petersen C, Thames HD. The challenge of p53 as prognostic and predictive factor in Hodgkin's or non-Hodgkin's lymphoma (review). Ann Hematol 2001; 80: 2-8.

54. Rybárová S, Hodorová I, Muri J, Mihalik J, Adamkov M, Svajdler M, Piovarci D, Mirossay L. Prognostic significance of p53 protein and $\mathrm{X}$-ray repair cross-complementing protein 1 in non-small cell lung cancer. Tumori 2011; 97 (1): 79-85.

55. Di Como CJ, Urist MJ, Babayan I, Drobnjak M, Hedvat CV, Teruya-Feldstein J, Pohar K, Hoos A, Cordon-Cardo C. p63 expression profiles in human normal and tumor tissues. Clin Cancer Res 2002; 8 (2): 494-501.

56. Dotto J, Pelosi G, Rosai J. Expression of p63 in thymomas and normal thymus. Am J Clin Pathol 2007; 127 (3): 415-420.

57. Adamkov M, Halasova E, Rajcani J, Bencat M, Vybohova D, Rybarova S, Galbavy S. Relation between expression pattern of p53 and surviving in cutaneous basal cell carcinomas. Med Sci Monit 2011; 17 (3): 74-80.

58. Adams JM, Cory S. The bcl-2 protein family: Arbiters of cell survival. Science 1998; 281: 1322-1326.

59. Kusenda J. Bcl-2 family proteins and leukaemia. Neoplasma 1998; 45: $117-122$.

60. Park SH, Kim HK, Kim H, Ro JY. Apoptosis in thymic epithelial tumors. Pathol Res Pract 2002; 198 (7): 461-467.

61. Khoury T, Arshad A, Bogner P, Ramnath N, Zhang S, Chandrasekhar R, Wilding G, Alrawi S, Tan D. Apoptosis-related (survivin, $\mathrm{Bcl}-2$ ), tumor suppressor gene (p53), proliferation (Ki-67), and non-receptor tyrosine kinase ( $\mathrm{Src}$ ) markers expression and correlation with clinicopathologic variables in 60 thymic neoplasms. Chest 2009; 136 (1): 220-228.

62. Spaulding B, Pan D, Ghadersohi A, Nielsen G, Jensen S, Gellert F, Ling X, Zhang M, Black A, Li F. Characterization of the $12 \mathrm{C} 4$ survivin monoclonal antibody and insight into the expression of survivin in human adult tissues. Histopathology 2006; 49 (6): 622-633.

63. Adamkov M, Lauko L, Balentova S, Pec J, Pec M, Rajcani J. Expression pattern of anti-apoptotic protein survivin in dysplastic nevi. Neoplasma. 2009; 56 (2): 130-135.

64. Adamkov M, Výbohová D, Horáček J, Kovalská M, Furjelová. Survivin expression in breast lobular carcinoma: Correlations with normal breast tissue and clinicomorphological parameters. Acta Histochem 2013; 115 (5): 412-417.

65. Halasova E, Adamkov M, Matakova T, Vybohova D, Antosova M, Janickova M, Singliar A, Dobrota D, Jakusova V. Expression of Ki-67, Bcl-2, Survivin and 553 proteins in patients with pulmonary carcinoma. Adv Exp Med Biol 2013; 756: 15-21.

66. Xing Z, Conway EM, Kang C, Winoto A. Essential role of survivin, an inhibitor of apoptosis protein, in T cell development, maturation, and homeostasis. J Exp Med 2004; 199 (1): 69-80.

Received September 12, 2011. Accepted January 23, 2013. 